\title{
A Conceptual Inquiry: What May Retranslation Offer for Translation Studies Research?
}

\author{
Alper Zafer GÜNEŞ*
}

The purpose of this article is to lead a discussion regarding the nature of the retranslation concept. A growing body of literature on the subject attests to some challenges about how to connect various studies around the same concept. Outi Paloposki and Kaisa Koskinen (2010), for one, point out the problematic borders between various practices and underline the relevance of definitional and methodological considerations in retranslation research in their article entitled "Reprocessing Texts: The Fine Line between Retranslating and Revising." Advocating that retranslation discussions cannot abstain from how translation is approached as a concept in the first place as a further point, the current article refers back to the definitional leg of Translation Studies research. Similar problems were deemed "unproductive" (9) by Theo Hermans (1985) in "Translation Studies and a New Paradigm" in favor of a "goal-directed" approach (14) in the past. It is reiterated here that essentialist positions need to be sidestepped to gain new results with translational practices and theoretical underpinnings of concepts recognized for possible connections between different studies. For a possible progress in research, Gideon Toury's (1980) working definition for translation has been critically interpreted for retranslation. By proposing "assumed retranslation," the article believes that the retranslation concept will be operationalized with a focus concentrated on circumstances of retranslation practices, and accumulating data sharing the same conceptual terrain will help understand nature, reasons and consequences of retranslation products better.

Keywords: translation concepts; progress in research; critical rereading; assumed retranslation; Gideon Toury

\section{Research Rationale}

An increasing interest in retranslation research also prompts conceptual questioning in the field of Translation Studies. Among the most prominent researchers in this regard are Outi Paloposki and Kaisa Koskinen. Their 2010 article entitled "Reprocessing Texts: The Fine Line between Retranslating and Revising" is a case in point. In that article, the scholars question "neat categorizations" of revision and retranslation, because both categories fail in the face of the "reality." Based on their extensive research, the scholars claim that textual profiles rather

\footnotetext{
* Translator at Abdullah Gül University, Kayseri; PhDc at Istanbul 29 Mayıs University. E-mail: azafergunes@gmail.com; ORCID ID: https://orcid.org/0000-0001-5070-3415. (Received 11 February 2019; accepted 10 June 2019)
} 
reveal a "multi-layered schema" of practices from correction to a new translation (47). This trail of argument is followed when they observe that "the actual categorizing of translation into first and subsequent translations . . . is ultimately misleading - unless we accept the claim that retranslation can be anything, from a slight editing of a previous translation to a completely different text" (37). Their way of formulation suggests that the latter is an option, but what they really argue is that the label might be deceiving. Thus, they warn that researchers "may be leaving out the real distinctions (or non-distinctions) - the label of retranslation (like that of revising) covers a great many different kinds of reworkings" (47). In this regard, on the one hand, they refrain from drawing a line as implied in their title, and on the other hand, despite their acute depiction of the state of the phenomenon based on data, the scholars do not provide an alternative or revised framework for future work as a starting point. They suffice with warnings of pitfalls and stick to the same definition in their retranslation entry for the Handbook of Translation Studies: "Retranslation (as a product) denotes a second or later translation of a single source text into the same target language" (Koskinen and Paloposki 2010, 294). The fact that they find retranslation category problematic but do not provide an alternative approach has been the motivation for this current study into the nature of that problem. ${ }^{1}$ This reading and the following ones have been done in search of a theoretical and conceptual framework for the author's ongoing $\mathrm{PhD}$ dissertation entitled "Queries on Translation Concepts, Projects and Politics: Concealed Retranslations of Ahmet Hamdi Tanpınar in English.” For this fundamental phase of the research, two questions have been formulated. Firstly, why is not the concept of retranslation working? Secondly, when we spot a problem with some concepts, how can we proceed? The first question seeks an answer around how retranslation is defined in the first place taking into account theoretical and philosophical roots of such an act, and the second one aims to point out that seeing defining as hypothesis building could serve the new assertions better as they can be tested in research.

The questions have been guiding towards an idea of progress in which alternative frameworks can also be built on past research in the field, and that idea has informed much of the following discussion. The second section lays down two existing senses in which progress has been discussed with regard to retranslation and continues with a focus on definitional

\footnotetext{
${ }^{1}$ The claimed research problem was first formalized for an oral presentation at the 5 th International Asoscongress at Y1ld1z Technical University, Istanbul on October 26, 2018.
} 
drawbacks to create a ground for another possible way of progress. The drawbacks argument is shaped around two ideas. Firstly, retranslation-centered definitions seem partially constructed, and retranslation research could better evolve within a more holistic (see also the final section) understanding including how translation is understood. Secondly, theoretical definitions may not be treated the same as dictionary entries. In order to assert the latter, connections between theories, worldviews and scientific methods are cited. The third section introduces why a rereading could be beneficial, and the fourth section proposes a known alternative afresh. The last section is intended to show the merits of the suggested concept within existing discussions in place of a conclusion.

\section{Progress and Deadlock in Research}

It seems that progress, particularly in the retranslation branch, is a shared concern in Translation Studies. Françoise Massardier-Kenney (2015), for instance, opens her article with the observation that "the critical literature on the retranslation of literary texts focuses on a fairly small number of recurrent questions or themes (i.e. what are the reasons for retranslating certain texts; how are retranslations different from first translations; why do translations get dated and, as critics claim, original texts don't, in particular)" (73). Supporting this claim, the retranslation hypothesis is still being tested (Deane-Cox 2014) although its limits have already been pointed out (Susam-Sarajeva 2003; Paloposki and Koskinen 2004; Brownlie 2006). Indeed, most recent research on retranslation has begun to point future directions. Koskinen (2019, chap. 20), herself, makes the following observation:

Researchers ... need to collaborate to compare and contrast their findings for retranslation research to move forward. Individual case studies are often illuminating, but they are not necessarily typical. They are selected for analysis because they somehow stand out. Making generalisations on the basis of accumulated case studies is therefore quite risky. (emphasis added)

She reports that one direction has been "compiling national histories of translation," a "move from cases to systems." So, progress appears as a shared concern in retranslation research in the sense of engaging in new discussions and collaborating on research results, and will be revisited in connection to a rereading below. Before that, what needs to be addressed are some reasons for the hindrance before progress so that the alternative suggestion to be proposed below may make more sense, and conceptual confusion seems a justified starting 
point with its relevance for the object matter of any research.

Paloposki and Koskinen (2010) refer to revision and retranslation as "confused" categorization (43), and it seems to result from a need to separate a "clearly," "whole" (43) or "completely new translation" (47) from the rest of translational outcomes. This claim places at the crux of the discussion how they, as researchers, approach the concept of 'translation' in the first place. In this regard, "translated again" (29) becomes tautological or at best partial for retranslation, because it does not tackle the question of what translation is. This initial consideration is deemed important in the sense that it determines subsequent positions towards subcategories. The scholars also accept the fact that different starting points are problematic for the comparison of research results (30), but they only question "intuitive assumptions" with regard to 'retranslation' (31), and it is hypothesized here that this partial approach which bypasses 'translation' is the reason behind conceptual confusions and what is blocking alternative frameworks.

This problem is not endemic to them. In other research as well, conceptual confusions manifest themselves. Two recent case studies from Turkish Translation Studies exemplify a similar situation. This time, the confusion does not arise between retranslation and revision but between intralingual and re-translation. It shows that within the limits of one book, scholars may classify the same unit of analysis differently depending on their conceptual approach to translation. Toska (2015), for instance, sees intralingual translation as the exchange of old words with "one in current usage" for linguistic equivalence. Hence, she prefers the category of retranslation to explain her case as linguistic and cultural "renewal" of a source text (83-4). For Berk Albachten (2015), though, the concept of intralingual translation already enables a discussion of "linguistic, translational and ideological norms" (165), and the same case becomes an intralingual translation (166; see also Güneş 2019).

As Gambier (2018) informs within the context of "deconstruct[ing] our own concepts and open[ing] up to new ones," these confusions may be due to the fact that "people work ... with cognitive categories they are (consciously or not) used to" and "it is easier to rely on known territories (geographical area, language family and conceptual network) than to question them" (22). Hence, the confusions are related to different concepts of "Translations" (Halverson 2010, 384) adopted by scholars as their starting points or more precisely to their theoretical bases.

Gernot Hebenstreit (2007), in an article where he analyses "definition patterns" (199) in a corpus of publications in light of definition theories in philosophy of science and 
terminology, writes:

Concepts as elements of a theory differ from non-theoretical concepts by way of their formation. . . . Scientific concepts, especially in the humanities, are constructed in the process of theory formation. . . . For that reason, scientific terminology is not only field-specific, but also theory-bound. These concepts and their definitions must always be seen against the background of the theory to which the concept belongs. (204; emphasis added)

This is a crucial observation and allows one to claim that the label of retranslation does not float freely in Translation Studies but is embedded in some assumptions if not deliberate theoretical formulations. Depending on differing initial assumptions, then, it would be possible to make different assertions with regard to the same object. For instance, if one begins the research assuming that "from the point of view of the target literature, all translation implies a degree of manipulation of the source text for a certain purpose" (Hermans 1985, 11), it would also be logical to assume all (re)translating is ideological. One might also base arguments on Lefevere $(1985,234)$ and claim "translation is probably the most obvious instance of rewriting. ... Yet all different forms of rewriting tend to work together in a literary system. No translation, published as a book, is likely to give you just the translation." One following argument could classify editing and (re)translating as rewrites. Yet again, if one observes a contemporary translation practice "interacting with a modern translation system" where "new cognitive constraints [are introduced] by altogether reconfiguring translational writing and revision into a new production form with less writing and revision, more editing of TM matches, and more post-editing of MT suggestions" (Jakobsen 2019, chap. 4), revision/editing could seem an integral part of (re)translating. So, it all comes to where one stands with regard to the object of inquiry. Whether it is acknowledged or not, there is always a position and any discussion of a scientific position would touch upon scientific methods and their philosophical foundations.

"From philosophy of science point of view," Hebenstreit (2007) further claims, "it is crucial to determine whether a piece of text is a definition, a hypothesis or an empirical generalization" (emphasis added). His point directly concerns a scientific method in which testability and repeatability of claims are emphasized. Chesterman ([2008] 2017) takes this assertion one step further when he formulates that classifications and definitions are already hypotheses which are interpretive: "the interpretation of $X$ is hypothesized to be $Y$, or simply $X$ is interpreted as $Y$ " (226). In a similar manner with Hebenstreit, Chesterman attributes some 
importance to hypothesis formulation considering it "a major step in the development of the scientific method" ([2007] 2017, 6). Thanks to hypothesis testing, one does not have to trust "the authority of the claimer," "tradition" or "intuition alone" but can check "empirical claims against evidence" (6). The latter point also concerns progress. If it were not for hypotheses, "first discovering and proposing them, then testing them, then refining them," researchers would be "condemned to simply go round and round in circles and to reinvent the wheel for ever" ([2000] 2017, 130). This, however, does not mean there is one scientific method, because science further depends on how one sees the world.

Halverson (2010) applies the last claim to concepts and writes, "talking about a concept of translation in Translation Studies ... means immediately butting up against fundamental issues concerning how one views the world and things in it, the feasibility or appropriate means of knowing anything about that world" (378). In the example of concepts, she basically refers to the "three basic questions" concerning one's position on ontology, epistemology and methodology: "Does (social) reality exist? Is it knowable? How can we acquire knowledge about it?" (Corbetta 2003, 13). When one knows that theorizing does not take place in a vacuum, that it starts from certain assumptions and accordingly has certain effects, and that concepts and definitions also share those implications as parts of theories, philosophical roots of one's concepts become a matter of inquiry. If those roots are not discerned, researchers risk subscribing to commonsensical formulations unawares, which are Aristotelian definitions for the current problematic case.

Halverson conducts extensive conceptual research in Translation Studies and discusses different parts of her findings in several articles. Halverson (1999) claims, "categorization is not based on objective qualities inherent in real-world objects but is dependent on and determined by properties of the human cognizer" (6). That is why, she does not advocate "classical theory, more specifically, the theory of Aristotelian categories" (5). Halverson describes them with two features: "first, categories are linked directly with an observerindependent, objective reality; second, the link is provided by the listing of necessary and sufficient conditions, which match directly with the essential features of the object in question" (5). The danger with this type of essentialist categorizing and defining is that they are prone to fail both hard sciences and humanities.

Chesterman ([2000] 2017, 130), for one, does not see any "difference here in principle between hard and soft sciences, nor even between empirical and hermeneutic approaches" in 
this regard. Believing that "extra precision tends to reduce the extension of a term," he reminds Pluto's story in astronomy ([2008] 2017, 230), which is still a hot debate. On September 10, 2018, a CNN article entitled "Pluto Is Most Definitely a Planet and Should Never Have Been Downgraded, Say Some Scientists" brought up this discussion. When the International Astronomical Union decided to define the concept of planet, Pluto no longer met all planetary criteria and was added to a new category, dwarf planet, but many still disagree with existing classification criteria as new evidence emerges, according to the article. In humanities, the situation is already more delicate, because "concepts ... tend to have fuzzy borders ... [and] are often mental constructions of abstract object" (Hebenstreit 2007, 204). In this regard, Aristotelian definitions could mean applying essential features on the "hybrid" (Paloposki and Koskinen 2010, 39) and "rhizomatic" (Brownlie 2006, 155) phenomena of (re)translating, which defies essentialism. In similar lines, Chesterman (2019) warns under "Risky rhetoric" that "in TS, the sentence 'translation is X' could easily be taken as a lexical definition [a dictionary or terminological standard], but this would be misleading if it is really intended as a stipulative one, to be glossed as 'I define translation as X, for present purposes (because ....)." This brings the discussion back to the point where the need to differentiate between a definition or hypothesis in research was stressed. Unless we believe our concept can be a standard, what we actually mean with its definition is a hypothesis to be tested and revised against new data for possible progress. Thanks to their rigorous testing, Paloposki and Koskinen (2010) contradict with the existing definition of retranslation but continue to treat the concept as a lexical definition rather than revising it within a holistic framework.

\section{Old Problem, New Guise}

Under the light of the above analysis on the place and nature of concepts in a scientific field, it is now possible to answer the first question why the concept of retranslation is not working as indicated by Paloposki and Koskinen's (2010) data. If it is acknowledged that concepts are theory-laden and as such have philosophical implications with regard to one's position towards knowledge, an incongruence emerges between these scholars' non-essentialist epistemology and essentialist conceptualization of retranslating as evidenced by their emphasis on "a new translation," cited in the second section with the adverbs 'clearly, whole, completely.' Such an emphasis suggests that these scholars might have "translation proper" (Jakobson 
[1959] 2000) in mind, and could deny the label of retranslation for a case if some parts of it were intralingually translated. Other starting points from a "prototype concept" (Halverson 1999) or "cluster concept" (Tymoczko 2007, chap. 2) would yield different answers or not see an existential problem concerning retranslation in the first place. So, the problem may be associated with the scholars' partial approach to the phenomenon which disregards the fact that the translation concept is already hybrid and might include revisions from various parallel sources or editors. Such influences are difficult to track in the absence of translation drafts, and existing previous translations only make them more visible in retranslations.

This assertion does not mean that revision and retranslation cannot be separated as two distinct practices. It might indeed be fruitful to handle them separately, yet again a case for its reasons seems to be in order. Chesterman ([2008] 2017, 231) calls this procedure a "conceptual testing" for the assessment of interpretive hypotheses: "if $X$ is interpreted as $Y$, added value will ensue (the added value being that we will understand $\mathrm{X}$ better, be able to examine it fruitfully, derive further interesting research questions, solve a problem, improve a situation, and so on)." Chesterman offers this kind of a testing in light of the fact that interpretive hypotheses "are not tested directly against empirical evidence (are they true?) but against pragmatic criteria (are they conceptually useful, insightful?)" ([2007] 2017, 6). If one, then, would like to separate revising from translational practices (cf. Koskinen 2019, "Revising and retranslating"), the added value of such a division seems to be in need of justification.

Paloposki and Koskinen's (2010) retranslation is not an empirical category, but the concept is constructed by the scholars as a research framework (36), and its definition stands as their hypothesis or claim. The scholars themselves inform that "retranslations cannot be picked out from bibliographical databases the way authors, translators or source languages can, as

\section{there is no search word or bibliographical field for the crucial piece of information that a} translation is in fact a retranslation" (36; emphasis added). ${ }^{2}$ That is why, in whatever way they handle the concepts, "their actual or potential usefulness needs to be demonstrated, so that their added value as conceptual research tools is made clear." This kind of a justification refers to operationalization of concepts. We might "split" them up or "lump" together but need to

\footnotetext{
${ }^{2}$ Berk Albachten and Tahir Gürçağlar (2019a, chap. 11) offer further insights in this regard: "In the case of a bibliography of retranslations, the research filter not only includes the term 'translation,' but also 'retranslation' . . . [and] the prior research filters chosen by the researcher or by the compilers of the primary bibliographical source already add a bias and carry an inherent definition of (re)translation." Against this challenge, they "adopt different classificatory approaches for older and more modern works" in their own bibliographical research of retranslations.
} 
explain "for what purposes" and make useable (Chesterman 2019, chap. 1).

Conceptual discussion is an old one in Translation Studies. Researchers might devote considerable time to make their concepts more precise, but what also matters seems like "doing" something with them (Chesterman [1998] 2017, 98). Chesterman does not see concepts as an end in themselves but as means to an end which is "for translation theory to adopt something like a standard empirical methodology, one in which hypotheses can be proposed and tested, and then corroborated or falsified" (98). That is why, it is advocated here, as the answer to the second question, when a problem with some concepts is pinpointed, not only modification is a more viable way to proceed, but also operationalization of modified concepts might be preferable so that future research can build on previous findings.

Paloposki and Koskinen $(2010,47)$ agree that "binary categorization into first and retranslations is not always helpful; neither is the categorization into revisions and retranslations. It is more a question of a continuum where different versions seamlessly slide together or even coalesce." In her latest article, Koskinen (2019, chap. 20) reiterates this position by writing "reprocessed texts come in many shapes and sizes, and . . it may well be impossible to reach fixed categorisations." These are all very valuable but firstly ignore that translation is already a fluid concept and secondly does not make their claim usable and show a covert tendency to keep those concepts apart based on proper translation: "before any final classification of data a close textual comparison of the (re)translations is needed to determine whether they are indeed new translations or are modified older translations" (Koskinen and Paloposki 2010, 294; emphasis added). In view of continued and growing interest in retranslation concept in Translation Studies, the need for alternative frameworks, in this regard, cannot be overemphasized (see Alvstad and Assis Rosa 2015a; Cadera and Walsh 2017; Berk Albachten and Tahir Gürçağlar 2019b).

\section{Assumed Retranslation}

Hans J. Vermeer (1994) opens his "Translation Today: Old and New Problems" with "a feeling of frustration" due to the fact that "the same problems and the same affirmations about the same problems are repeated again and again" and lists some progressive movements in the field from "paradigmatic change" to a "perfect circle" which is basically coming back to the initial point (3). Lastly, he mentions and operationalizes "re-interpreting a theory" which he 
describes as "exegesis" (7-9). Remembering that Translation Studies already went through similar phases in the discussions around a translation concept, exegesis of an existing theory is believed to offer a kind of forward movement. Theo Hermans (1985) in "Translation Studies and a New Paradigm" hails target-orientedness as a "more coherent and goal-directed type of investigation" after lamenting that "translation scholars have often been their own worst enemies ... for continuing to ask similarly unproductive essentialist questions (how is translation to be defined?, is translation actually possible?, what is a 'good' translation?)" (9). In similar lines, Gideon Toury's assumed translation $(1985,20 ; 2012,27$; cf. 1980, 37, 43) has been re-interpreted critically here for retranslation research.

"Assumed retranslation" as a term was actually coined by Paloposki and Koskinen (2010) in their indeed insightful article in the manner that "categories may also be historically unstable: 'assumed retranslations' (cf. Toury 1995) may turn out to be revisions and vice versa" (45); however, they once again refer to retranslations in the sense of 'new translations' excluding the possibility that revisions may be integral to the practice and make no further use of the concept. It is intended as a theoretical concept here to analyze retranslations in any form they appear. It is well known that Toury approaches the field at three separate but interconnected levels: theoretical, descriptive and applied (2012, part 1). Assumed translation is interpreted as referring to the "possible/probable" relationships at the theoretical level (13). ${ }^{3}$ Believing in the potential usefulness of retranslation research, assumed (re)translation is proposed to shift focus onto additional parameters which might pose challenges in description such as previous translations and their effect(s) on the unit of analysis. These parameters are already being discussed in various publications mentioned above, but the endeavor here is a gesture to Toury's holistic design: "a possibility of describing fully and systematically all the relationships that may possibly obtain between TT and ST (in full or in part), in one and the same theoretical frame of reference, hence by means of one ordered set of terms" $(1980,92)$.

Therefore, Toury's formulations (2012) have been appropriated for 'assumed retranslation.' It is a "working hypothesis providing guidelines" to analyze "all utterances in a [target] culture which are presented or regarded as [re]translations, on any grounds whatever, as well as all phenomena within them and the processes that gave rise to them" (27; emphasis

\footnotetext{
${ }^{3}$ Tymoczko $(2002,17)$ also supports this view: Toury's "definition operates on the level of theory" and has theoretical significance.
} 
in original). Accordingly, "the contents of the notion of "assumed [re]translation"” are the source-text, transfer and relationship postulates (28) with the addition of an existing translation postulate. Postulates are taken as factors constraining re-translating here contrary to a belief that they are "a priori" criteria (Halverson 2008, 350-1). "Their existence is posited rather than factual, at least not of necessity. Therefore, rather than constituting answers, they are designed to give rise to questions, to be addressed by anyone wishing to study [re]translation in context" (Toury 2012, 28; bold emphasis added). They allow formulation of research questions and contextualization of objects of analysis. At the end of an analysis, a retranslation concept might emerge which is different from the one initially accepted, such as the 'fully new interlingual translation.' That is why as Toury advocates, "the point here is precisely to tackle questions such as why a text, or an activity, was (or was not) presented/regarded as [re]translational" (28) and understand the phenomenon in its relevant context.

Such a rereading has been carried out with a research project in mind. It serves as a theoretical and conceptual framework for the analyses of two retranslations from Ahmet Hamdi Tanpinar which either overtly disregarded a previous translation as in the case of Saatleri Ayarlama Enstitüsü or covertly ignored it as for Huzur.

Through the concept of concealed retranslation ${ }^{4}$, nature of these two products including reasons behind and effects of translational decisions is aimed to be discussed. It is believed that together with the conceptual discussion, what (re)translation is and the questions of why this (kind of) (re)translation is like this and what consequences these (re)translations have provide a framework as close to a shared ground as possible in Translation Studies (cf. Chesterman and Arrojo [2000] 2017, 17-24). The research would also be misguided due to interdependencies between data and theory if only one leg was prioritized, thus each element discussed from problematization to solution proposal is considered focal although the case studies below occupy a relatively less space as they are discussed elsewhere in detail.

Some research results pertaining to Saatleri Ayarlama Enstitüsü are available in Güneş (2018). Therein it was stated that the retranslation "represented a more reductionist and at times misguided understanding of the work" (379). In order to exemplify what prompted the research with a particular focus on retranslatedness, the back-cover blurb of the Penguin edition is quoted

\footnotetext{
${ }^{4}$ The concept might indicate a nonexistent, unimportant or blurry distinction between first and later translations (cf. Toury 2012, 93-4), or a deliberate act of concealment of the fact that there is an existing translation wherever a distinction is found to be valid.
} 
below:

An uproarious tragicomedy of modernization, in its first-ever English translation . . . the Time Regulation Institute, [is] a vast organization that employs a hilariously intricate system of fines for the purpose of changing all the clocks in Turkey to Western time. Recounted in sessions with his psychoanalyst, the story of Hayri Irdal's absurdist misadventures plays out as a brilliant allegory of the collision of tradition and modernity, of East and West, infused with a poignant blend of hope for the promise of the future and nostalgia for a simpler time.

Firstly, besides the fact that there is an existing translation in English, Armağan Ekici, points at another misconception in his online article "How to Regulate Time" (T24, March 16, 2016). He locates the passage to Western time within the time of the Ottoman Sultan Abdulhamid II, not the Republic when the Institute was conceived: "Working hours in public institutions and railways changed to European time. Clock towers, which were becoming widespread at the end of the Ottoman period, showed European time. The 1926 [republican] law on time regulation legalised the existing situation. ..." These historical details situate the novel in a different context. Conversely, the passage is most vividly depicted in the retranslation's U.S. cover with Arabic and Roman numerals and most misleadingly in the U.K. cover with an Ottoman fez in the new republican institution.

Figure 1. Left to right: Front covers of the first translation and retranslation (for the U.S. and U.K. markets) of Saatleri Ayarlama Enstitüsü
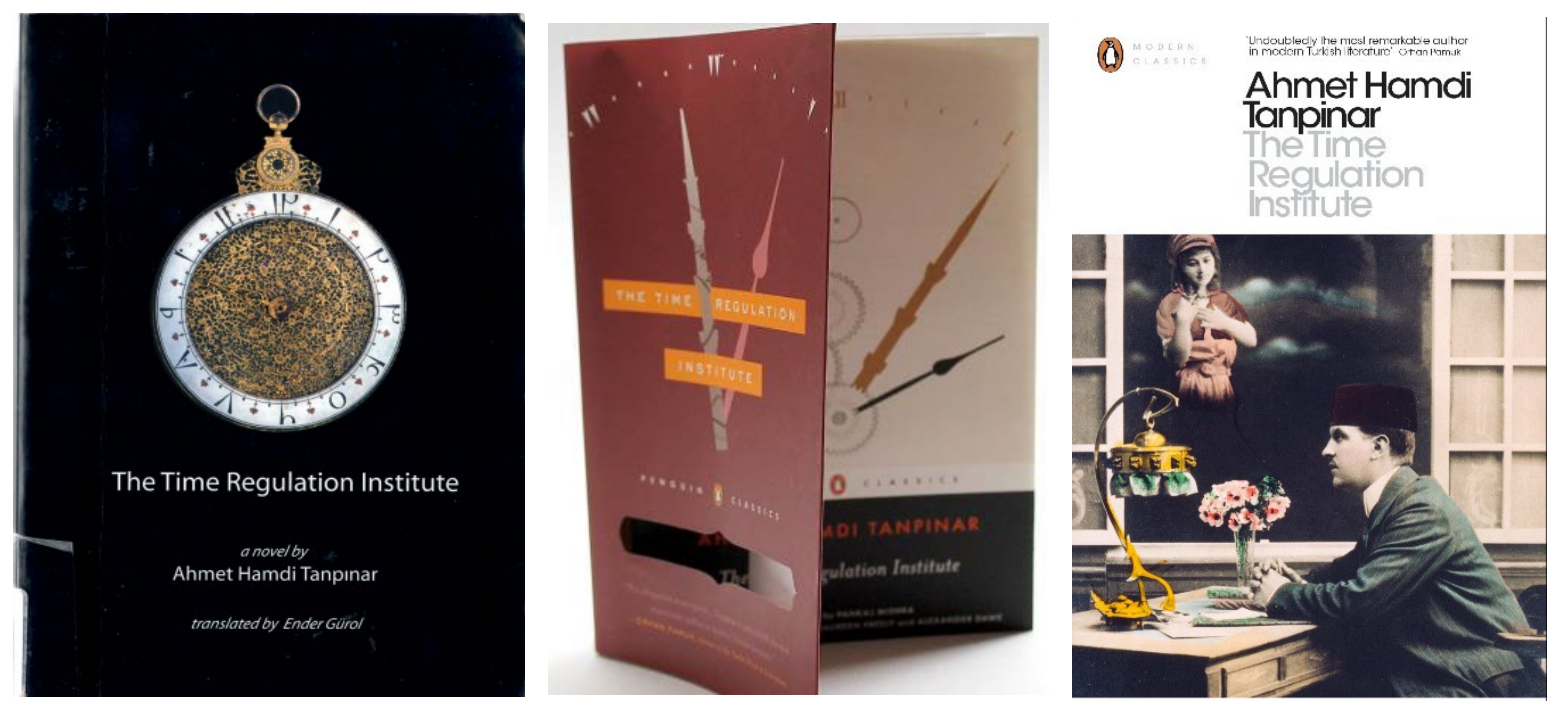

Secondly, the said sessions with the psychoanalyst are particularly intriguing. 
Originally, Irdal's misadventures are only parts of the novel; however, there is an additional section in the format of a letter which the author dictated to his assistant but was not published. This letter never appeared in reprints of the novel, and critics seem divided if it should indeed be a part. What is peculiar about this short alternative ending is a discovery about Irdal's paranoia, which makes his adventures a "tragic comedy" rather than blatant criticism (Alptekin 2001, 65). Only in this scenario, it is possible to claim that Irdal's life stories were told in some sessions, and the letter is not a part of the retranslation's textual make-up.

This observation was made in an initial extratextual analysis in view of the Turko-Tatar edition. Since the Turkish editions did not include the letter, when it came up in research, there would not be much of a reason for it to stand out. However, it is included in the first translation, and the promotional mix-up raises the question if it was ever considered for publication in the retranslation as well. It could hint at multiplicity of meanings in the novel rather than a melting pot of experiences evoked in the quotation below. In his introductory analysis for the retranslation, available online as "Ahmet Hamdi Tanpınar and the Waiting Room of History" (Guardian, February 28, 2015), Mishra concludes that the novel shows,

in our postmodern cages, glimpses of another kind of civilization. It also mourns, more eloquently and sensitively than any novel I know, the obscure sufferings of people in less "developed" societies - those who, uprooted from their old ways of being, must languish eternally in the waiting room of history.

Even with small data, Voyant Tools with its digital humanities methods could reveal some discernable patterns in Mishra's introduction. The Collocates tool, for instance, lists 'melancholy,' 'loneliness,' 'desperate,' 'defiantly' within 5 words on each side of the word 'Istanbul.' Besides this bleak atmosphere of the city which is largely absent in The Time Regulation Institute, the word 'mind' is a frequent word according to the Terms tools, which is mostly used in reference to Tanpinar's other novel in English retranslation, A Mind at Peace. That is how the research was extended to translational decisions in both retranslations to see if this particular reading stood alone. In comparative analyses with sources, congruency of data and "intermediary concepts" (Toury 2012, 106) were observed, and first translations served as control samples. An example in Güneș (2018) is reproduced with emphasis in table 1 to show that Mishra's reading is not uncoordinated.

Table 1. Excerpts from Tanpınar's Saatleri Ayarlama Enstitüsü and its translations 


\begin{tabular}{lll}
\hline Retranslation (2014) & Original (1961) & First translation (2001) \\
\hline $\begin{array}{l}\text { As my son once told me, I } \\
\text { had no experience of what } \\
\text { he called "proper, } \\
\begin{array}{l}\text { organized employment." } \\
\text { (51) }\end{array}\end{array}$ & $\begin{array}{l}\text { Oğlumun dediği gibi, } \\
\text { "hakikî çalışmanın } \\
\text { nizamından" geçmedim. }\end{array}$ & $\begin{array}{l}\text { As my son says, I have not } \\
\text { been subjected to "the } \\
\text { ordeal of real work." (66) }\end{array}$ \\
\hline
\end{tabular}

In isolation, the difference between 'proper, organized employment' and 'the ordeal of real work' could seem trivial, but for Tanpınar's purposes, it might be pointing towards a solution out of or turning a blind eye to 'the waiting room of history.' The first translation features a translated critique by Berna Moran, a leading Turkish literary critic, in place of an introduction. Moran highlights that Irdal's son is one of the few characters in the novel who dodges criticism. According to him, there is a moral rationale behind this choice which is to advise people to focus on productivity ([1978] 2001, 21-2). 'Hilariously intricate system of fines' of the Institute, mentioned in the blurb above, gain new meanings under this morale. Rather than ridiculing a whole society, Tanpınar might have wanted them to understand the importance of real work satirizing useless endeavors for their time, i.e. establishing a massive clock-setting institution (an alternative translation and emphasis to time regulation for saatleri ayarlama). Ekici reminds, "the time signal had been broadcast on the radio for almost twenty years" around the time the novel appeared.

The retranslator's voice in A Mind at Peace shows itself under different strategies. Explicitation, for instance, is a clearly discernible pattern in Erdağ Göknar's translation and accentuates certain aspects of its source as emphasized in table 2.

Table 2. Excerpts from Tanpınar's Huzur and its translations

\begin{tabular}{|c|c|c|}
\hline Retranslation (2008) & Original (1949) & First translation (2007) \\
\hline $\begin{array}{l}\text { For a long time Mümtaz } \\
\text { couldn't determine whether } \\
\text { the hüzün of inexplicable } \\
\text { melancholy falling about } \\
\text { them and the memory-hued } \\
\text { twilight had emanated from } \\
\text { the evening or from the song } \\
\text { itself. (I.V.35) }\end{array}$ & $\begin{array}{l}\text { Mümtaz uzun zaman etrafa } \\
\text { çöken hüznün, o hatıra } \\
\text { renkli ışığın bu akşamdan } \\
\text { mı, yoksa besteden mi } \\
\text { geldiğini anlıyamamıştı. (52) }\end{array}$ & $\begin{array}{l}\text { Mümtaz could not tell for } \\
\text { some time whether the } \\
\text { melancholy that had set in, } \\
\text { that colored brightness, } \\
\text { originated from the twilight } \\
\text { or the music. (46) }\end{array}$ \\
\hline
\end{tabular}

Orhan Pamuk is frequently mentioned in reviews of $A$ Mind at Peace, and despite sound 
speculation in some other aspects, ${ }^{5}$ it may not be relevant to ascertain if Tanpınar's melancholy is as inexplicable as Pamuk's hüzün or would deserve the extra attention if it was not for Pamuk in this case. Regardless, it came to hold a special place in A Mind at Peace and set the tone for the reception of The Time Regulation Institute as well. Mishra, for instance, finds Tanpinar's success in "his sense of foreboding and loss, and his evocation, in particular, of the melancholy, or hüzün, of those doomed to arrive late, and spiritually destitute, in history." This overview shows in the preferred silence of competing alternatives, retranslations expanded on dominant and reductionist discourses.

Toury's (2012) theory provides the holistic framework within which all pertinent factors affecting the production and reception of retranslation products are discussed with their consequences. The first-translation claim triggers the research with the question if retranslatedness is concealed; the extratextual materials raise further questions regarding the reception of the original; the textual analysis collaborates on a certain representation which is found to be connected to another retranslation from the same author and some familiar discourses in the target culture; the findings from both retranslations gain prominence in comparison with not only the originals but also the first translations, which are largely absent in discussions and point at alternative translation solutions in reality. The framework acknowledges that an object of study is not "neutral" (17); has blurry borders in "a class of phenomena" (69); accommodates varied comparative methodologies in virtue of the unique nature of each translation (106); thus, it allows proper contextualization and helps position retranslations better in their relevant target contexts.

\section{Justifications for the Proposed Concept}

To conclude, some justifications will be listed as discussed above related to 'conceptual testing.' Various readings into retranslation research presented so far are not exhaustive, mostly lacking literature in languages other than English on the topic; however, two studies have been spotted which problematize a translation concept with regard to retranslation. Firstly, Esra Birkan Baydan (2015) in "Ideological Encounters: Islamic Retranslations of the Western Classics" makes similar uses of conceptual questioning in research by problematizing "the

\footnotetext{
${ }^{5}$ A thorough analysis including the above excerpts related to Huzur was carried out for the unpublished paper "Politics of Translating: A Descriptive Study on A Mind at Peace" submitted to Prof. Işıın-Bengi Öner in Fall 201718 at Istanbul 29 Mayis University.
} 
discourse of 'full translation' [which] derives from the notion of 'fidelity' to the 'original"' (237). For her very different purposes, the author necessarily dismantles the (re)translation concept, only this time as it appears in the public eye. Secondly, Kristiina Taivalkoski-Shilov (2015) starts discussing retranslating from a translation concept. She also modifies Toury's (2012) "assumed translation" and Koskinen and Paloposki’s (2010) "retranslation" concepts to include indirect translations into a retranslation corpus. Since Paloposki and Koskinen (2010, 38-9) also include indirect first translations into their corpus, her endeavor shows the relevancy of hypothesis modification in Translation Studies research. So, both scholars' individual studies show similarities with the purposes of the present research and provide it with some degree of justification. The claim here is not a direct link with each studies' main line of argumentation but to point at partial methodological similarities in other studies concerning retranslation in the manner of conceptual inquiry and working with hypothesis.

It is also believed that assumed retranslation could cater for documented needs in existing retranslation research. If indirect (re)translation is thought relevant for research purposes, for instance, postulates allow inclusion and exploration of different parameters for any possible "systemic constellation" (Toury 2012, 18). If revision is found to be widespread in retranslating in "whatever target sector it is found to be a fact of" (23), it could then be considered as a norm and part of the practice in "a scalable continuum" (65). In a similar manner, "multiple sources of explanations for what is going on in retranslations" (Brownlie 2006, 167-8) could be unveiled with adequate contextualization (cf. Alvstad and Assis Rosa 2015b, 12) in Toury's framework. Most of all, the notion would allow "a systemic approach towards the phenomenon of retranslation" (Cadera 2016, 11) with "a sustained methodology" (9). In this regard, it would also offer comparability between results for possible generalizations (cf. Koskinen 2019, chap. 20), "probabilistic predictions" (Chesterman [1998] 2017, 106) and a way to "test the generality of our descriptions and expose them to the risk of falsification, or at least to rigorous criticism" (107). As the research is conducted within a holistic framework (Toury 1991; Bengi-Öner 2001), it would enable scholars to benefit from the wealth of past studies on translation. The kind of holism envisaged refers not only to sub-branches but also to meta-branches such as the Philosophy or History of Translation Studies as theorized by Işın Bengi-Öner as early as $2001(85,91)$. Bengi-Öner's assertions seem indispensable when one surprisingly finds out that existing publications might approach the phenomena of retranslation as if a totally new procedure and discover similar translational parameters afresh. 
Last but not the least, the concept of assumed (re)translation is based on "family resemblance" (Wittgenstein qtd. in Toury 2012, 69), which is composed of "open-ended series of similarities, analogies, overlaps and relationships that can be observed in varied practices in different contexts" and thus it is "decentred and rhizome-like, moving from case to case and, in the process, accommodating divergent and even incommensurable instances and practices" (Hermans 2013, 84).

Hermans (2013) actually criticizes Toury's translation definition and directs his praise to "cluster concepts" which are in turn based on "family resemblances" (Tymoczko 2007, chap. 2). This conflict opens up the ground where Toury criticism will be addressed in further research within scientific and philosophical discussion which will also detail how Toury has been reinterpreted critically. 


\section{References}

Alptekin, Turan. 2001. Ahmet Hamdi Tanpınar: Bir Kültür, Bir Insan. Istanbul: İletişim.

Alvstad, Cecilia, and Alexandra Assis Rosa, eds. 2015a. "Voice in Retranslation." Special issue, Target 27 (1). doi:10.1075/target.27.1.

2015b. "Voice in Retranslation: An Overview and Some Trends." Target 27 (1): 3-24. doi:10.1075/target.27.1.00int.

Bengi-Öner, Işın. 2001. “Çeviribilimde 'Bütünleyici Bir Yaklaşım’ Üzerine Eleştirel Görüşler ve Öneriler." [Critical views and suggestions on 'an integrated approach' in Translation Studies.] Chap. 2.1 in Çeviri Kuramlarını Düşünürken [Reflections on theories of translation]. Istanbul: Sel Yayıncilık.

Berk Albachten, Özlem. 2015. "The Turkish Language Reform and Intralingual Translation.” In Tradition, Tension and Translation in Turkey, edited by Şehnaz Tahir Gürçağlar, Saliha Paker, and John Milton, 165-180. Amsterdam: John Benjamins.

Berk Albachten, Özlem, and Şehnaz Tahir Gürçağlar. 2019a. "The Making and Reading of a Bibliography of Retranslations." Chap. 11 in Perspectives on Retranslation: Ideology, Paratexts, Methods, edited by Özlem Berk Albachten and Şehnaz Tahir Gürçağlar. New York: Routledge. Google Book.

_ eds. 2019b. Perspectives on Retranslation: Ideology, Paratexts, Methods. New York: Routledge. Google Book.

Birkan Baydan, Esra. 2015. "Ideological Encounters: Islamic Retranslations of the Western Classics." In Tradition, Tension and Translation in Turkey, edited by Şehnaz Tahir Gürçağlar, Saliha Paker, and John Milton, 233-251. Amsterdam: John Benjamins.

Brownlie, Siobhan. 2006. "Narrative Theory and Retranslation Theory." Across Languages and Cultures 7 (2): 145-170. doi:10.1556/Acr.7.2006.2.1.

Cadera, Susanne M. 2016. "Literary Retranslation in Context: A Historical, Social and Culture Perspective." In Literary Retranslation in Context, edited by Susanne M. Cadera and Andrew Samuel Walsh, 5-18. Oxford: Peter Lang.

Cadera, Susanne M., and Andrew Samuel Walsh, eds. 2016. Literary Retranslation in Context. Oxford: Peter Lang.

Chesterman, Andrew. (1998) 2017. "Causes, Translations, Effects." Paper 9 in Reflections on Translation Theory: Selected Papers 1993-2014. Amsterdam: John Benjamins.

. (2000) 2017. "A Causal Model for Translation Studies.” Paper 10 in Reflections on Translation Theory: Selected Papers 1993-2014. Amsterdam: John Benjamins. 
. (2007) 2017. "On the Idea of a Theory." Paper 1 in Reflections on Translation Theory: Selected Papers 1993-2014. Amsterdam: John Benjamins.

. (2008) 2017. "The Status of Interpretive Hypothesis." Paper 18 in Reflections on Translation Theory: Selected Papers 1993-2014. Amsterdam: John Benjamins

. 2019. "Moving Conceptual Boundaries: So What?" Chap. 1 in Moving Boundaries in Translation Studies, edited by Helle V. Dam, Matilde Nisbeth Brøgger, and Karen Korning Zethsen. London: Routledge. Google Book.

Chesterman, Andrew, and Rosemary Arrojo. (2000) 2017. "Shared Ground in Translation Studies." Paper 2 in Reflections on Translation Theory: Selected Papers 1993-2014. Amsterdam: John Benjamins.

Corbetta, Piergiorgio. 2003. "Paradigms of Social Research." Chap. 1 in Social Research. Theory, Methods and Techniques. Translated by Bernard Patrick. London: SAGE Publications.

Deane-Cox, Sharon. 2014. Retranslation: Translation, Literature and Reinterpretation. London: Bloomsbury.

Gambier, Yves. 2018. "Concepts of Translation." In A History of Modern Translation Knowledge: Sources, Concepts, Effects, edited by Lieven D'hulst and Yves Gambier, 19-38. Amsterdam: John Benjamins.

Güneş, Alper Zafer. 2018. "The Retranslation of The Time Regulation Institute: A Project of Respect or Prejudice?" In Çeviribilimde Güncel Tartışmalardan Kavramsal Sorgulamalara [From recent discussions to conceptual reflections in Translation Studies], edited by Seda Taş, 379-411. Istanbul: Hiperyayın.

2019. "Why Would Institutional Memory Matter for the Translation Studies?" In Çeviribilimde Araştırmalar [Research in Translation Studies], edited by Seda Taş, 215234. Istanbul: Hiperyayın.

Halverson, Sandra L. 1999. "Conceptual Work and the 'Translation' Concept.” Target 11 (1): 1-31. doi:10.1075/target.11.1.02hal.

2008. "Translations as Institutional Facts: An Ontology for 'Assumed Translation."” In Beyond Descriptive Translation Studies: Investigations in Homage to Gideon Toury, edited by Anthony Pym, Miriam Shlesinger, and Daniel Simeoni, 343-362. Amsterdam: John Benjamins.

_ 2010. "Translation." In Handbook of Translation Studies: Volume 1, edited by Yves Gambier and Luc van Doorslaer, 378-384. Amsterdam: John Benjamins.

Hebenstreit, Gernot. 2007. "Defining Patterns in Translation Studies: Revisiting Two Classics of German Translationswissenschaft." Target 19 (2): 197-215. 
doi:10.1075/target.19.2.03heb.

Hermans, Theo. 1985. "Introduction: Translation Studies and a New Paradigm." In The Manipulation of Literature: Studies in Literary Translation, edited by Theo Hermans, 7-15. London: Croom Helm.

2013. "What Is (Not) Translation?" In Routledge Handbook of Translation Studies, edited by Carmen Millán and Francesca Bartrina, 75-87. London: Routledge.

Jakobsen, Arnt Lykke. 2019. "Moving Translation, Revision, and Post-editing Boundaries." Chap. 4 in Moving Boundaries in Translation Studies, edited by Helle V. Dam, Matilde Nisbeth Brøgger, and Karen Korning Zethsen. London: Routledge. Google Book.

Jakobson, Roman. (1959) 2000. "On Linguistic Aspects of Translation.” In The Translation Studies Reader, edited by Lawrence Venuti, 113-8. London: Routledge.

Koskinen, Kaisa. 2019. "Revising and Retranslating." Chap. 20 in The Routledge Handbook of Literary Translation. Edited by Kelly Washbourne and Ben Van Wyke. London: Routledge. Google Book.

Koskinen, Kaisa, and Outi Paloposki. 2010. "Retranslation." In Handbook of Translation Studies: Volume 1, edited by Yves Gambier and Luc van Doorslaer, 294-98. Amsterdam: John Benjamins.

Lefevere, André. 1985. "Why Waste Our Time on Rewrites? The Trouble with Interpretation and the Role of Rewriting in an Alternative Paradigm." In The Manipulation of Literature: Studies in Literary Translation, edited by Theo Hermans, 215-243. London: Croom Helm.

Massardier-Kenney, Françoise. 2015. "Toward a Rethinking of Retranslation.” Translation Review 92 (1): 73-85. doi:10.1080/07374836.2015.1086289.

Moran, Berna. (1978) 2001. "The Time Regulation Institute: A Critical Essay.” Introduction to The Time Regulation Institute, by Ahmet Hamdi Tanpınar, 1-23. Translated by Ender Gürol. Madison: Turko-Tatar Press.

Paloposki, Outi, and Kaisa Koskinen. 2004. "A Thousand and One Translations: Revisiting Retranslation." In Claims, Changes and Challenges in Translation Studies, edited by Gyde Hansen, Kirsten Malmkjær, and Daniel Gile, 27-38. Amsterdam: John Benjamins.

. 2010. "Reprocessing Texts: The Fine Line between Retranslating and Revising." Across Languages and Cultures 11 (1): 29-49. doi:10.1556/Acr.11.2010.1.2.

Susam-Sarajeva, Şebnem. 2003. "Multiple-entry Visa to Travelling Theory: Retranslations of Literary and Cultural Theories.” Target 15 (1): 1-36. doi:10.1075/target.15.1.02sus.

Tanpınar, Ahmet Hamdi. 1949. Huzur. Istanbul: Remzi. 
1961. Saatleri Ayarlama Enstitüsü. Istanbul: Remzi.

2001. The Time Regulation Institute. Translated by Ender Gürol. Madison: TurkoTatar Press.

—. 2007. Inner Peace. Translated by Ender Gürol. Madison: Turko-Tatar Press.

- 2008. A Mind at Peace. Translated by Erdağ Göknar. New York: Archipelago Books. Kobo e-book.

- 2014. The Time Regulation Institute. Translated by Maureen Freely and Alexander Dawe. New York: Penguin.

Taivalkoski-Shilov, Kristiina. 2015. "Friday in Finnish: A Character's and (Re)translators' Voices in Six Finnish Retranslations of Daniel Defoe's Robinson Cruose." Target 27 (1): 58-74. doi:10.1075/target.27.1.03tai.

Toska, Zehra. 2015. "Ahmet Mithat's Hulâsa-i Hümâyunnâme: A Curious Case of Politics of Translation, 'Renewal,' Imperial Patronage and Censorship." In Tradition, Tension and Translation in Turkey, edited by Şehnaz Tahir Gürçağlar, Saliha Paker, and John Milton, 73-86. Amsterdam: John Benjamins.

Toury, Gideon. 1980. In Search of a Theory of Translation. Jerusalem: Porter Institute.

1985. "A Rationale for Descriptive Translation Studies." In The Manipulation of Literature: Studies in Literary Translation, edited by Theo Hermans, 16-41. London: Croom Helm.

1991. "What are Descriptive Studies in Translation Likely to Yield apart from Isolated Descriptions?" In Translation Studies: The State of the Art; Proceedings of the First James S. Holmes Symposium on Translation Studies, edited by Kitty M. van LeuvenZwart and Ton Naaijkens, 179-192. Amsterdam: Rodopi.

- 2012. Descriptive Translation Studies — and Beyond. 2nd expanded ed. Amsterdam: John Benjamins. First published 1995.

Tymoczko, Maria. 2002. "Connecting the Two Infinite Orders: Research Methods in Translation Studies." In Crosscultural Transgressions, edited by Theo Hermans, 9-25. Manchester: St. Jerome.

—. 2007. "Defining Translation." Chap. 2 in Enlarging Translation, Empowering Translators. London: Routledge.

Vermeer, Hans J. 1994. “Translation Today: Old and New Problems.” In Translation Studies: An Interdiscipline, edited by Mary Snell-Hornby, Franz Pöchhacker, and Klaus Kaindl, 3-16. Amsterdam: John Benjamins. 